\title{
A pictorial presentation of 3.0 Chicago Classification for esophageal motility disorders
}

\author{
Apresentação em imagens da Classificação de Chicago versão 3.0 \\ das doenças da motilidade esofagiana
}

Fernando Augusto Herbella ${ }^{1}$, Priscila Rodrigues Armijo ${ }^{1}$, Marco Giuseppe Patti ${ }^{2}$

\begin{abstract}
High resolution manometry changed several esophageal motility paradigms. The 3.0 Chicago Classification defined manometric criteria for named esophageal motility disorders. We present a pictorial atlas of motility disorders. Achalasia types, esophagogastric junction obstruction, absent contractility, distal esophageal spasm, hypercontractile esophagus (jackhammer), ineffective esophageal motility, and fragmented peristalsis are depicted with high-resolution manometry plots.
\end{abstract}

Keywords: Manometry/methods; Esophageal motility disorders; Esophageal achalasia/classification

\section{RESUMO}

A manometria de alta resolução mudou vários paradigmas da motilidade digestiva. A Classificação de Chicago, na versão 3.0, definiu critérios manométricos para as doenças da motilidade esofagiana. 0 presente artigo é um atlas das dismotilidades descritas. Tipos de acalásia, obstrução ao nível da junção esofagogástrica, contrações ausentes, espasmo esofagiano distal, esôfago hipercontrátil, motilidade esofagiana ineficaz e peristalse fragmentada são mostradas em traçados de manometria de alta resolução.

Descritores: Manometria/métodos; Transtornos da motilidade esofágica; Acalásia esofágica/classificação

\section{INTRODUCTION}

High resolution manometry (Figure 1) has clear and inherent advantages over conventional manometry, despite its higher cost. ${ }^{(1)}$ High resolution manometry detailed analysis of esophageal peristalsis changed several esophageal motility paradigms, including new manometric parameters and different classification for named "motility

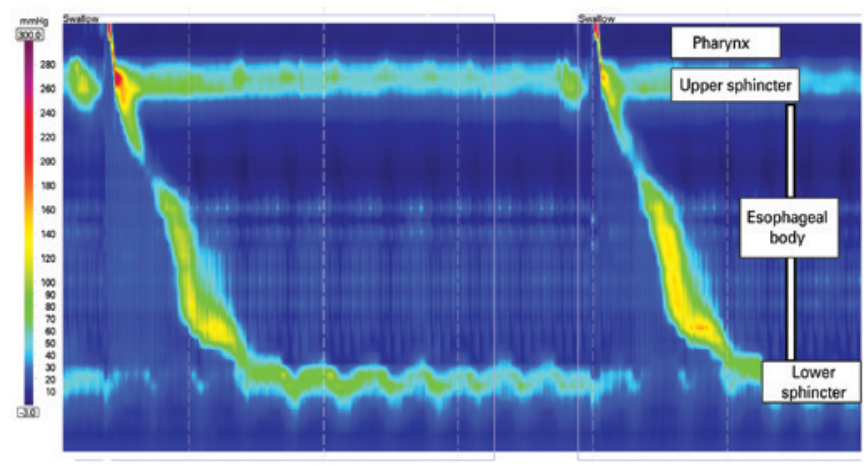

Figure 1. Normal high resolution manometry

disorders based on pressure topography", the Chicago classification, ${ }^{(2)}$ which was recently revised. ${ }^{(3)}$

We present a pictorial atlas of the motility disorders according to the 3.0 Chicago Classification with highresolution plots.

\section{Achalasia}

Chicago Classification divided achalasia into three subtypes according to esophageal pressurization ${ }^{(4)}$ (Figure 2). Type I is characterized by $100 \%$ failed contractions and no esophageal pressurization; type II has panesophageal pressurization in at least $20 \%$ of swallows; and type III is defined by the presence of preserved fragments of distal peristalsis or premature contractions for at least $20 \%$ of the swallows. ${ }^{(3)}$ This classification may be applied to Chagas' disease esophagopathy as well, although type III is rarely, if ever, seem. ${ }^{(5)}$

\footnotetext{
Escola Paulista de Medicina, Universidade Federal de São Paulo, São Paulo, SP, Brazil.

2 University of Chicago, Chicago, Illinois, Estados Unidos.

Corresponding author: Fernando Augusto Herbella - Rua Diogo de Faria, 1.087, room 301 - Vila Clementino - Zip code: $04037-003$ - São Paulo, SP, Brazil - Phone: (55 11) 3926-7610 E-mail: herbella.dcir@epm.br
} 


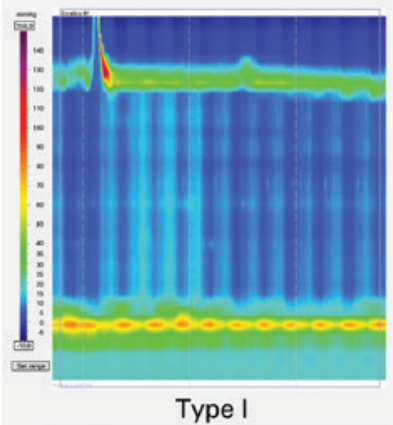

Type I

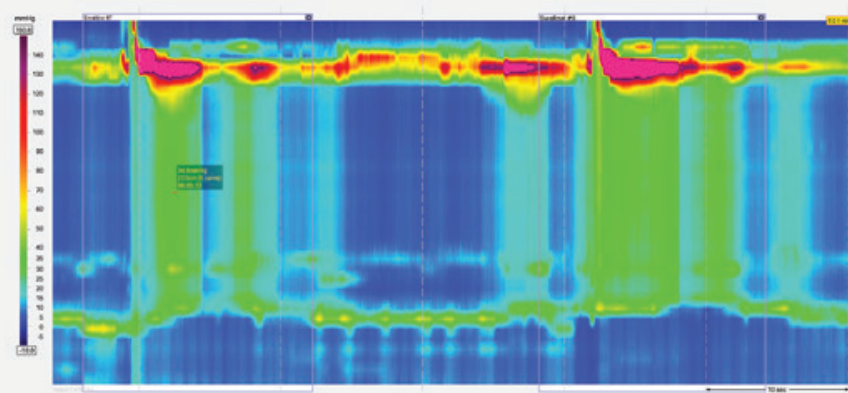

Type ॥

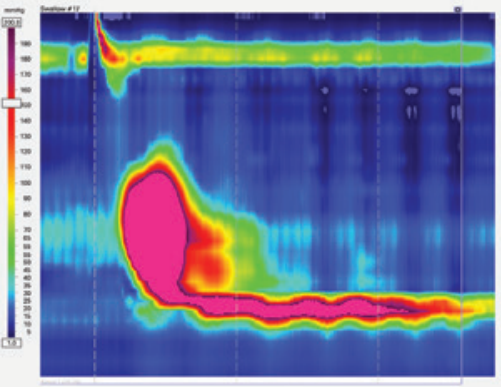

Type III

Figure 2. Achalasia types

\section{Esophagogastric junction obstruction}

Esophagogastric junction obstruction (Figure 3) is characterized by an elevated residual pressure of the lower esophageal sphincter (LES) measured by a new and more sophisticated tool, the integrated relaxation pressure $^{(6)}$ in the absence of criteria for achalasia (absence of peristalsis). ${ }^{(3)}$ This parameter measures the mean pressure of the 4 seconds of maximal deglutitive relaxation in the 10 -second window beginning at the beginning of the swallow (upper sphincter relaxation). It is a rare finding usually present in patients with dysphagia after operations at the esophagogastric junction. ${ }^{(7)}$

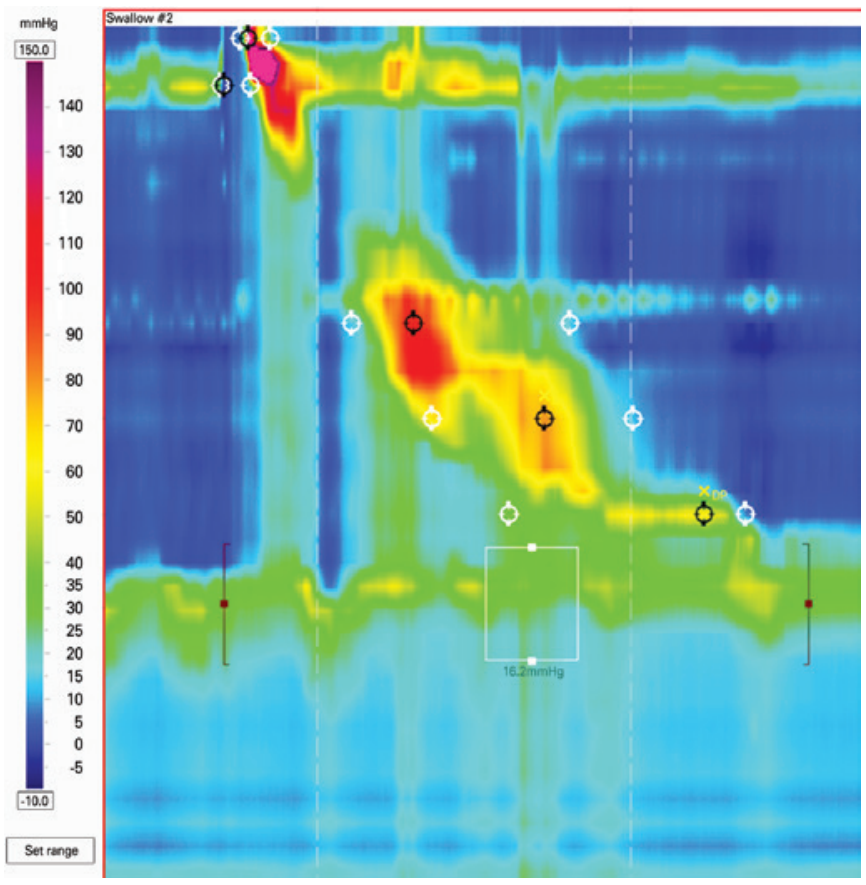

Figure 3. Esophagogastric junction obstruction in a patient after Nissen operation

\section{Absent contractility}

Absent contractility is characterized by aperistalsis in the setting of normal LES relaxation and absence of esophageal pressurization ${ }^{(3)}$ (Figure 4). This finding may be noticed in patients with connective tissue diseases, end-stage gastroesophageal reflux disease etc.

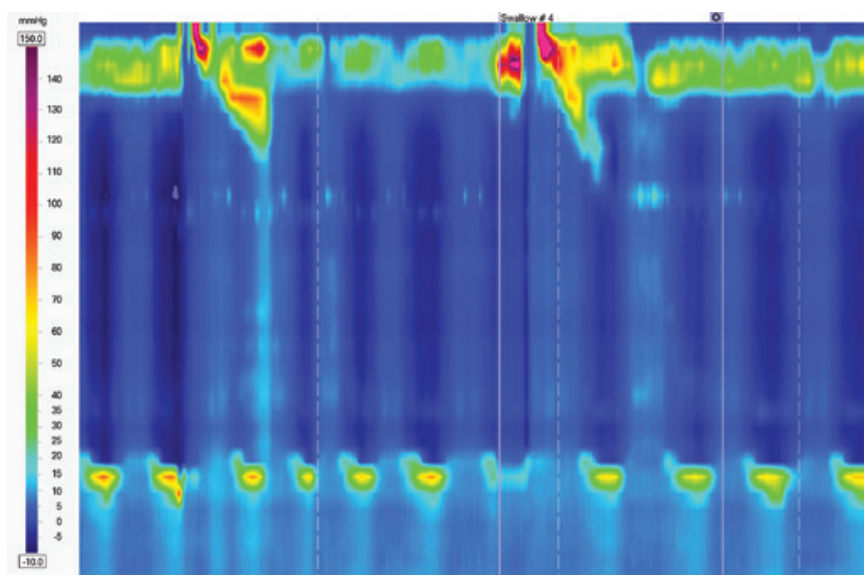

Figure 4. Absent contractility in a patient with scleroderma

\section{Distal esophageal spasm}

Distal esophageal spasm is defined by over $20 \%$ of premature contractions as measured by a new parameter, the distal latency (DL) $<4.5$ seconds $^{(3)}$ (Figure 5). The DL is the time interval between the beginning of the upper sphincter relaxation and the contractile deceleration point the manometric representation of the transition from the esophageal body to the epiphrenic ampulla regarded as an inflection of the peristaltic axis within $3 \mathrm{~cm}$ of the proximal margin of the LES. ${ }^{(8)}$

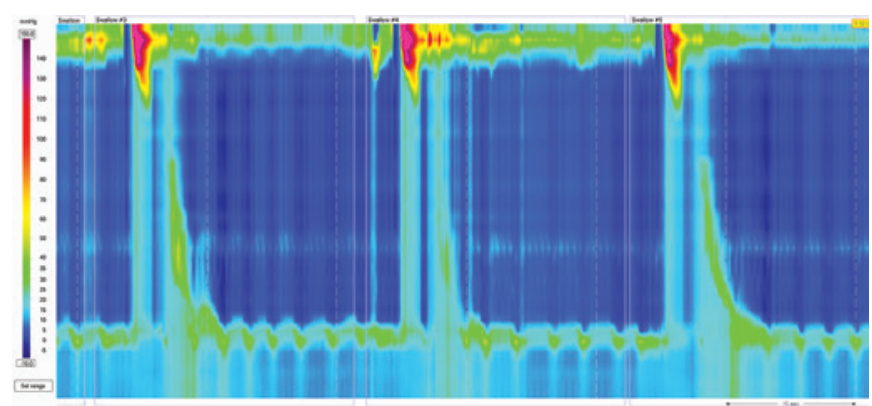

Figure 5. Distal esophageal spasm 


\section{Hypercontractile esophagus}

Hypercontractile esophagus (Jackhammer esophagus) is characterized by at least two swallows with hypercontractility as measured by the distal contractile integral (DCI ${ }^{(3)}$ (Figure 6). The DCI measures the contractile vigor combining the amplitude versus duration versus length of the distal esophageal contraction exceeding $20 \mathrm{mmHg}$ from the transition zone to the proximal margin of the LES. ${ }^{(9)}$ Hypercontractility is defined by DCI $>8,000 \mathrm{mmHg} . \mathrm{s.cm} \cdot{ }^{(3)}$ It may occur with esophagogastric junction obstruction, gastroesophageal reflux disease and eosinophilic esophagitis. ${ }^{(10)}$

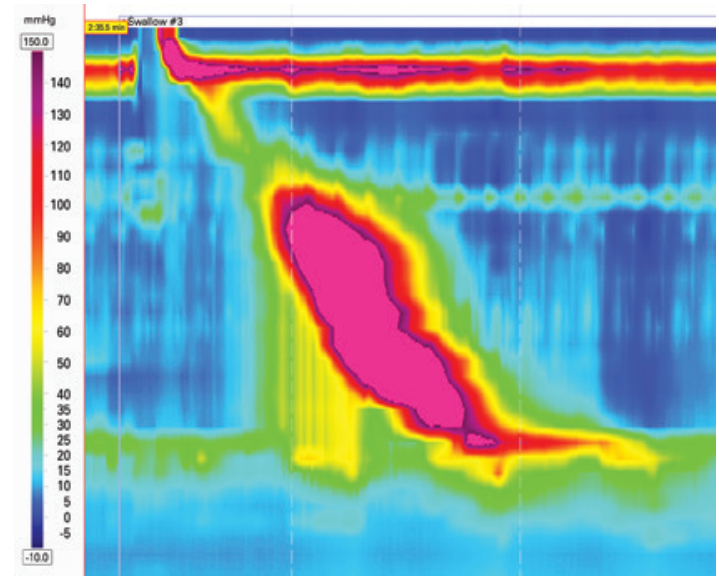

Figure 6. Hypercontractile esophagus

\section{Ineffective esophageal motility}

Ineffective esophageal motility is defined by $\geq 50 \%$ ineffective swallows (failed or weak - DCI $<450 \mathrm{mmHg} . \mathrm{s.cm})^{(3)}$ (Figure 7).

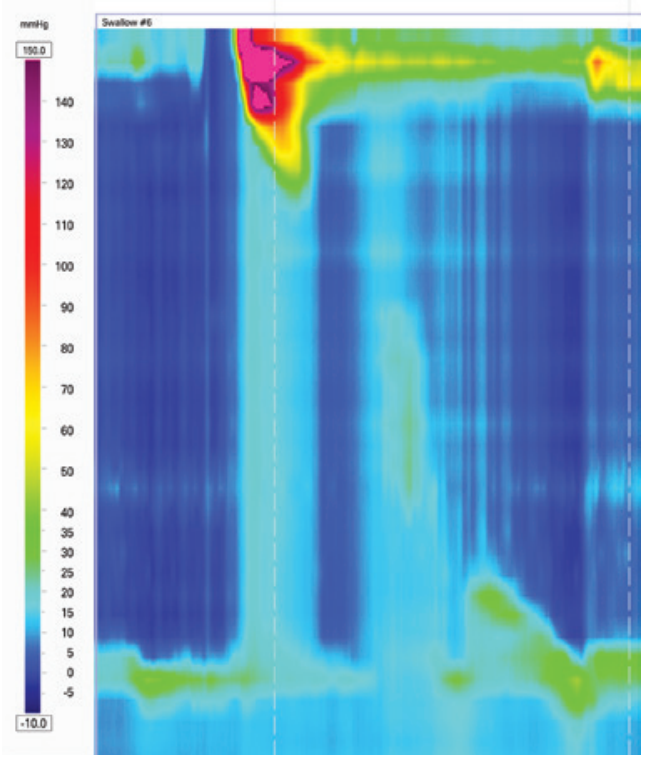

Figure 7. Ineffective esophageal motility in a patient with gastroesophageal reflux disease

\section{Fragmented peristalsis}

Fragmented peristalsis $\geq 50 \%$ fragmented contractions with DCI >450mmHg.s.cm ${ }^{(3)}$ (Figure 8). Although patients with fragmented peristalsis are more prone to have dysphagia, ${ }^{(11)}$ its clinical significance is still elusive.

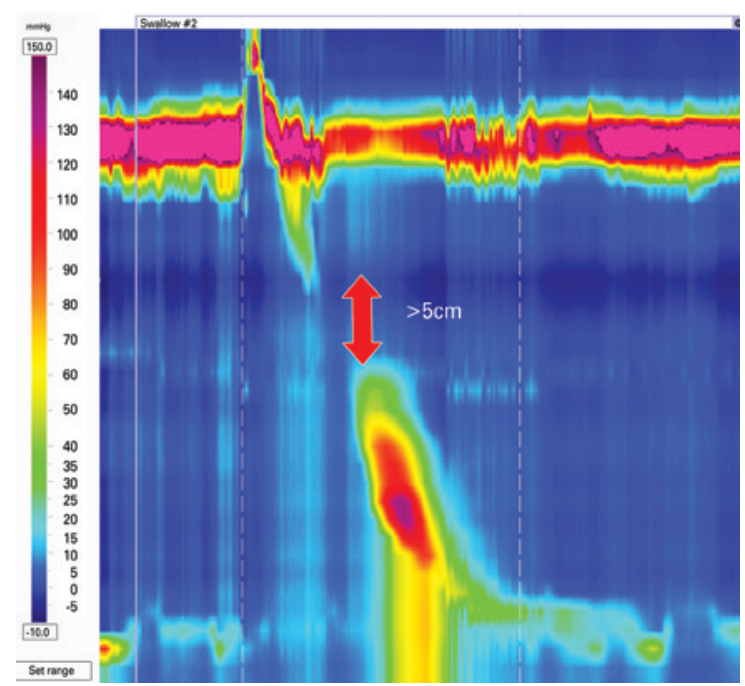

Figure 8. Fragmented peristalsis

\section{DISCUSSION}

Motility patterns to define named disorders have been motive of controversy since the era of conventional manometry. Different definitions exist although the classification by Richter was the most used by experts. ${ }^{(12)}$ High resolution manometry seems to bring a more intuitive and reproducible interpretation compared with conventional manometry, ${ }^{(13)}$ and more sophisticated tools to define old and new manometric parameters. Despite all improvements, and similarity with conventional manometry, some cases are still unclassified, and the real clinical significance of some Chicago Classification disorders is still under investigation.

\section{REFERENCES}

1. Herbella FA, Del Grande JC. [New ambulatory techniques for assessment of esophageal motility and their applicability on achalasia study]. Rev Col Bras Cir. 2008;35(3):199-202. Portuguese.

2. Kahrilas PJ, Ghosh SK, Pandolfino JE. Esophageal motility disorders in terms of pressure topography: the Chicago Classification. J Clin Gastroenterol. 2008;42(5):627-35. Review.

3. Kahrilas PJ, Bredenoord AJ, Fox M, Gyawali CP, Roman S, Smout AJ, Pandolfino JE; International High Resolution Manometry Working Group. The Chicago Classification of esophageal motility disorders, v3.0. Neurogastroenterol Motil. 2015;27(2):160-74.

4. Pandolfino JE, Kwiatek MA, Nealis T, Bulsiewicz W, Post J, Kahrilas PJ. Achalasia: a new clinically relevant classification by high-resolution manometry. Gastroenterology. 2008;135(5):1526-33. 
5. Vicentine FP, Herbella FA, Allaix ME, Silva LC, Patti MG. High-resolution manometry classifications for idiopathic achalasia in patients with Chagas' disease esophagopathy. J Gastrointest Surg. 2014;18(2):221-4; discussion 224-5.

6. Lin Z, Kahrilas PJ, Roman S, Boris L, Carlson D, Pandolfino JE. Refining the criterion for an abnormal Integrated Relaxation Pressure in esophageal pressure topography based on the pattern of esophageal contractility using a classification and regression tree model. Neurogastroenterol Motil. 2012;24(8):e356-63.

7. Scherer JR, Kwiatek MA, Soper NJ, Pandolfino JE, Kahrilas PJ. Functional esophagogastric junction obstruction with intact peristalsis: a heterogeneous syndrome sometimes akin to achalasia. J Gastrointest Surg. 2009;13(12):2219-25.

8. Pandolfino JE, Roman S, Carlson D, Luger D, Bidari K, Boris L, et al. Distal esophageal spasm in high-resolution esophageal pressure topography: defining clinical phenotypes. Gastroenterology. 2011;141(2):469-75.
9. Roman S, Pandolfino JE, Chen J, Boris L, Luger D, Kahrilas PJ. Phenotypes and clinical context of hypercontractility in high-resolution esophageal pressure topography (EPT). Am J Gastroenterol. 2012;107(1):37-45.

10. Martín-Domínguez V, Pérez-Fernández MT, Marinero A, Jusué-Irurita V, Caldas M, Santander C. Hypercontractile esophagus: Clinical context and motors findings in high resolution manometry. Rev Esp Enferm Dig. 2015;107(5):274-9.

11. Roman S, Lin Z, Kwiatek MA, Pandolfino JE, Kahrilas PJ. Weak peristalsis in esophageal pressure topography: classification and association with Dysphagia. Am J Gastroenterol. 2011;106(2):349-56.

12. Richter JE. Oesophageal motility disorders. Lancet. 2001;358(9284):823-8. Review.

13. Soudagar AS, Sayuk GS, Gyawali CP. Learners favour high resolution oesophagea manometry with better diagnostic accuracy over conventional line tracings. Gut. 2012:61(6):798-803. 